\title{
Klotho protein function among patients with type 1 diabetes
}

\author{
Justyna Flotyńska, Aleksandra Uruska, Aleksandra Araszkiewicz, Dorota Zozulińska-Ziółkiewicz \\ Department of Internal Medicine and Diabetology, Poznan University of Medical Sciences, Raszeja Hospital, Poznan, Poland
}

\begin{abstract}
The fibroblast growth factor 23 (FGF23) and Klotho system play a very important role in the regulation of the human body metabolism. On the one hand, they promote longevity, and on the other hand they promote insulin resistance. Nowadays, accelerated aging in diabetes as the main consequence of chronic complications of the disease is postulated. Signalling pathways induced by insulin, insulin-like growth factor (IGF-1), and their homologues play an important role in controlling the aging process. Because FGF23/Klotho system affects glucose metabolism and gene expression of antioxidant enzymes, changes in its concentration may be a marker of chronic complications of diabetes or a treatment option. Despite huge improvements in the treatment of diabetes, its chronic complications remain an important clinical problem. An interesting issue is the relationship between the concentration of FGF23/Klotho and management of the disease, duration, insulin resistance, and development of complications in type 1 diabetes. (Endokrynol Pol 2018; 69 (6): 696-704)

Key words: type 1 diabetes; longevity proteins; chronic complications of diabetes
\end{abstract}

\section{Introduction}

Diabetes mellitus type 1 (DM1) is a chronic, autoimmune disease [1]. The number of people with DM1 is still increasing in every part of the world [2]. Patients with DM1 have worse quality of life in comparison to healthy counterparts [3]. Late diagnosis and uncontrolled disease leads to the development of long-term complications that cause disability, inability to work, and increased premature mortality [4-6]. Among the traditional risk factors of chronic complications, a crucial role is played by hyperglycaemia [7] and insulin resistance [8], which includes decreased muscle, fat, and liver sensitivity to insulin [9]. Additional risk factors are dyslipidaemia [10], arterial hypertension [11], cigarette smoking [12], and inflammation [7]. The Diabetes Control and Complications Trial (DCCT) [1] showed that in patients with DM1 appropriate metabolic control, provided by intensive insulin therapy, is fundamental in prevention and management of angiopathy. Long-term normalisation of blood glucose level can significantly decrease the risk of occurrence and delay progression of diabetes complications [13, 14]. However, despite improvements in the diagnosis and treatment of DM1, chronic complications remain a relevant, clinical problem. Retinopathy is the main reason for blindness, diabetic kidney disease is a leading cause of end-stage kidney failure, and neuropathy is responsible for non-injury amputations [15]. Thus, we are still looking for new, non-traditional risk factors of diabetic angiopathy among DM1 patients [16].
The pathogenesis of chronic complications that occur among DM1 patients is very complicated. The most important factor is endothelial dysfunction causing microangiopathy, macroangiopathy, and neurodegeneration [17]. DM1 patients with associated microvascular complications have higher risk of accelerated atherosclerosis, which ultimately ends in cerebrovascular and cardiovascular events and premature death [18]. Small-vessel impairment is caused in the mechanism of oxidative stress and endothelial dysfunction [13, 19]. Hyperglycaemia and insulin resistance are the two major consequences of diabetes responsible for cardiovascular disorders [20]. They cause excessive reactive oxygen species (ROS) production, which at too high a level for a prolonged time or at an inappropriate subcellular location leads to impaired cellular function and cardiovascular pathology [20]. ROS activates nuclear poly (ADP ribose) polymerase (PARP), shunting early glycolytic intermediates into pathogenic signalling pathways. These changes cause decreased mitochondrial biogenesis and disturbed circadian clock synchronisation of glucose and lipid metabolism [20]. Another important pathomechanism causing angiopathic complications is increased inflammatory process [7]. Overproduction of reactive oxygen species (ROS) as a result of altered glucose metabolism and formation of advanced glycation end-products (AGE) activate nuclear factor $\kappa \mathrm{B}(\mathrm{NF \kappa})$ and other proinflammatory pathways. In combination with endothelial cell insulin resistance, these changes cause endothelial dysfunction manifesting itself by increased expression of 
adhesion molecules and other changes [21]. Nowadays, accelerated aging in diabetes is postulated as the main consequence of the mentioned mechanisms of chronic complications. Signalling pathways induced by insulin, insulin-like growth factor (IGF-1), and their homologues play an important role in controlling the aging of many organisms [22]. Because FGF23/Klotho system affects the processes associated with glucose metabolism and regulation of gene expression of antioxidant enzymes, changes in its concentration may be an important source of information about the development of chronic complications of diabetes.

\section{Function of the FGF23}

Fibroblast growth factor 23 (FGF23) and Klotho protein are an important part of the system regulating the metabolism of vitamin $\mathrm{D}$ and phosphate concentration. FGF23 is one of the newest members of FGF complex. This phosphatogenic hormone is synthesised and secreted by osteoblasts and osteocytes. To a lesser extent it is produced by salivary glands, skeletal muscles, breast glands, liver, and cardiac muscle. The kidneys are the main target organ for this protein [23-25]. FGF23 is responsible for the inhibition of kidney reabsorption of phosphates, their excretion by inhibiting the sodium-phosphate cotransporter, and reduction of the concentration of $1.25(\mathrm{OH})$ vitamin D3 by inhibiting $1 \alpha$-hydroxylase and stimulating 24-hydroxylase. Additionally, FGF23 inhibits the secretion of parathyroid hormone (PTH) [26]. The overflow of the FGF23 leads to the hypophosphataemia, reduction of $1.25(\mathrm{OH})_{2} \mathrm{D}$ concentration, and thus to rickets or osteomalacia. On the other hand, FGF23 deficiency causes the opposite situation, which implies the formation of calcifications in soft tissues. Hyperphosphataemia and $1.25(\mathrm{OH})_{2} \mathrm{D}$ stimulate secretion of FGF23, whereas reduction of phosphate supply has an inhibitory action [25]. The literature indicates that systemic phosphate balance and vitamin D concentration have the most significant effect on FGF23 concentration [27-29] (Figure 1). Another leptin is a less well-known regulatory factor. Recent research has reported about the relationship between abdominal obesity and increasing FGF23 concentration [30]. Leptin stimulates the synthesis of FGF23 in the bones. There is an association of elevated leptin and FGF23 concentration with dyslipidaemia and adipose tissue mass [31]. This may be a risk factor for the development of insulin resistance, metabolic syndrome, and cardiovascular deaths, particularly in patients with long-lasting type 1 diabetes mellitus and metabolic decompensation [32]. More and more data show that the family of fibroblast growth factors influence regulation and carbohydrate homeostasis [33].

\section{Klotho as FGF23 cofactor}

Klotho protein is a cofactor of FGF23 and is a necessary protein to affect FGF23 on the receptor [34]. It is a circulating hormone involved in insulin signalling, inflammation, and vascular homeostasis through its protective effects on the endothelium and antioxidant actions [35]. Klotho expression occurs in various tissues. The main synthesis site is the distal coils in the kidney, choroid plexus of the brain ventricles, and parathyroid glands. It also occurs in the liver, pancreas, and white adipose tissue [36]. It has two forms: membrane and secretory. Klotho protein has $\beta$-glucuronidase activity, and its secretory form is an endocrine regulator of glycoprotein function on the surface of cells [37]. The Klotho/FGF23 system works in reverse relation to vitamin D and according to the literature plays a comparable role to the PTH — vitamin D axis [23].

\section{Function of the Klotho protein}

Klotho is a very important protein with a broad spectrum of activity (Fig. 2). It affects glucose metabolism [38]. It is involved in the suppression of the insulin/IGF-1 pathway and thus participates in the regulation of cell function and growth. Signalling pathways induced by insulin, insulin-like growth factor (IGF-1), and their homologues play an important role in controlling the aging of many organisms [22]. This protein disrupts insulin-mediated phosphorylation, consequently inhibiting the activation of further proteins of the enzymatic pathway. In vitro, it has been demonstrated that this protein may also inhibit the phosphorylation of receptors previously activated by insulin or IGF-1. The activity of the secreted Klotho protein is specific for insulin and IGF-1 receptors because it does not show a similar effect to platelet-derived growth factor (PDGF) receptors and epidermal growth factor (EGF) receptors, which have tyrosine kinase activity $[39,40]$. The enzymatic activity of Klotho suggests that it may also modify N-glycans of insulin and IGF-1 receptors, thereby blocking their activity and/or reducing the number of these receptors on the surface of cells. It blocks insulin-stimulated glucose uptake and contributes to the development of insulin resistance and all of its consequences [39]. It is suggested that the co-operation of two mechanisms contributes to the extension of life: inhibition of IGF-1 signalling and increased resistance to the oxidative pathway [41]. Blocking signal transmission on the insulin-dependent or IGF-1-dependent pathway leads to inhibition of Akt kinase. Akt active kinase phosphorylates the FOXO transcription factor. Only the non-phosphorylated FOXO factor, which is located in cell nucleus, acts as a transcription factor. Proteins belonging to the FOXO 
family are responsible for cell differentiation, embryogenesis, neoplasia, and metabolism regulation [42]. An important function is the regulation of gene expression of antioxidant enzymes such as catalase or mitochondrial manganese superoxide dismutase (SOD2). These enzymes remove reactive oxygen species and contribute to the reduction of oxidative stress, which can be an important factor in the process of inhibiting the aging of organisms that have inhibited the insulin/IGF-1 pathway [39]. Klotho protein increases hyperplasia of adipose tissue, and mice without this gene are resistant to the development of obesity induced by a high-fat diet [43]. Studies on animal models have shown that mutations that inactivate the Klotho gene reduce survival time and cause many disorders that contribute to premature aging. These disorders include osteoporosis, hypogonadotropic hypogonadism, atherosclerosis, skin atrophy, and neurodegenerative changes. It was found that mice devoid of the FGF23 and Klotho gene also experienced thymus atrophy, decreased triglycerides and glucose levels, and increased cholesterol levels [36]. Studies on severe nodular calcification as a result of the missense mutation of the human Klotho gene indicate the essential function of the Klotho protein [44]. What is more, recent studies show a relationship between vascular expression of this protein with diabetes and coronary disease [45]. The FGF23/Klotho system, in addition to the regulation of electrolyte management, plays a very important role in regulating the metabolism of the human body. On the one hand it promotes longevity, and on the other hand it promotes insulin resistance.

\section{Is there a relationship between Klotho protein and type 1 diabetes?}

Diabetic kidney disease is one of the most serious complications in patients with DM1 and one of the main predictors of premature death [46]. Renal impairments cause changes in the concentration of the described proteins. Chronic kidney disease leads to increased levels of FGF23 with a concomitant decrease in Klotho protein. In the 2-3 phase of chronic kidney disease, when the phosphate is still normal and the PTH concentration is normal or moderately elevated, the concentration of FGF23 increases [47, 48]. Klotho-negative mice and patients with end-stage renal disease have common features such as hyperphosphataemia, vascular calcification, or high FGF23 concentration [49]. Diabetes mellitus as a chronic disease causes some complications, including nephropathy. It is also suggested that plasma Klotho concentration, or more precisely the disappearance of a compensatory increase in serum concentration, may be an early marker for predicting

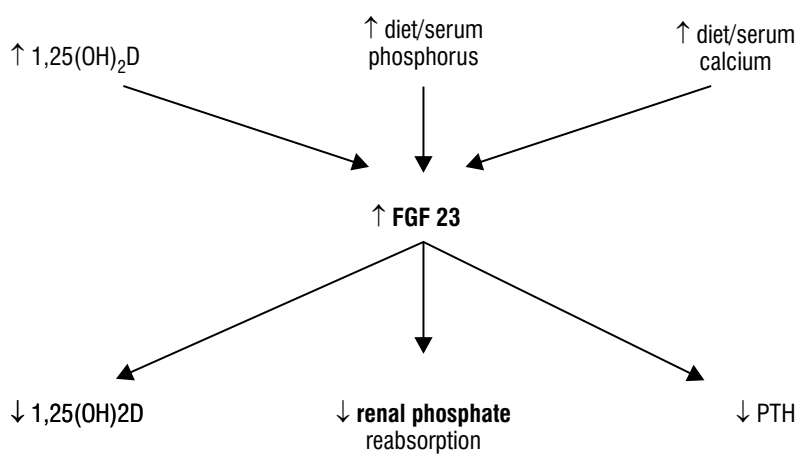

Figure 1. Regulation of fibroblast growth factor 23 (FGF23)

deterioration of renal function among patients with type 2 diabetes [50,51]. We also know that serum Klotho may have a protective effect against atherosclerosis and endothelial dysfunction in type 1 DM [52]. Guo et al. revealed that Klotho might exert its cardioprotective effects by protecting cells from inflammation and oxidative stress. Thus, this work demonstrated for the first time that the anti-aging protein Klotho might be a potential therapeutic agent to treat diabetic cardiomyopathy by inhibiting oxidative stress and inflammation [53]. Recently, endocrine fibroblast growth factors have become attractive targets in the treatment of metabolic diseases, and results highlight the relevant use of FGFs as potential biomarkers for the early diagnosis of metabolic diseases [54]. However, there are still few studies showing similar correlations among patients with type 1 diabetes. An interesting question is whether among people with type 1 diabetes, along with an increase in FGF23 concentration and, consequently, a decrease in Klotho concentration, the features of aging are revealed and intensified.

\section{Summary}

Nowadays, there are no data showing changes in FGF23 and Klotho concentrations in people with type 1 diabetes. The literature reports that protein concentrations from the fibroblast growth factor family are increased in first-degree relatives of DM2 patients with pre-diabetes and that there is a strong association between fibroblast growth factor 21 (FGF 21) and obesity and insulin sensitivity [55]. We know that Klotho levels among patients with type 1 diabetes mellitus might be affected by renal impairment, hyperglycaemia, and high insulin doses [56]. It is possible that the Klotho protein synthesised in the pancreas plays a completely different role from the known one. Recent studies have reported that the synthesis in pancreatic cells cause suppressing beta-cell apoptosis in patients with type 1 diabetes [57], and the findings of the latest studies suggest that the 


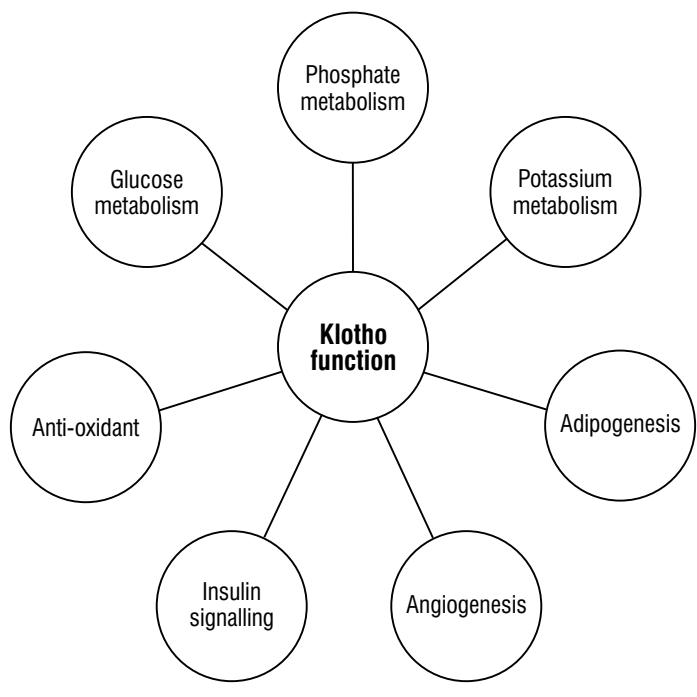

Figure 2. Function of Klotho

functional variant of the Klotho gene protects against the development of retinopathy in patients with DM1 [35]. An interesting issue is the relationship between the concentration of these proteins and the frequency and type of complications in people with type 1 diabetes, as well as the duration of the disease and the development of insulin resistance. We need more studies to clearly determine the relationship between FGF23 and Klotho protein concentrations with DM1.

\section{Acknowledgements}

Work financed from the Diabetes Poland grant.

\section{References}

1. Buschur E, Sarma AV, Pietropaolo M, et al. DCCT/EDIC Research Group. Self-reported autoimmune disease by sex in the diabetes control and complications trial/epidemiology of diabetes interventions and complications (DCCT/EDIC) study. Diabetes Care. 2014; 37(2): e28-e29, doi 10.2337/dc13-1890, indexed in Pubmed: 24459159.

2. IDF Diabetes Atlas. 7th edition. International Diabetes Federation, Brussels 2015 .

3. Nielsen HB, Ovesen LL, Mortensen LH, et al. Type 1 diabetes, quality of life, occupational status and education level - A comparative population-based study. Diabetes Res Clin Pract. 2016; 121: 62-68, doi: 10.1016/j.diabres.2016.08.021, indexed in Pubmed: 27662040.

4. Diabetes Control and Complications Trial Research Group. Effect of intensive diabetes treatment on the development and progression of long-term complications in adolescents with insulin-dependent diabetes mellitus: Diabetes Control and Complications Trial. Diabetes Control and Complications Trial Research Group. J Pediatr. 1994; 125(2): 177-188, indexed in Pubmed: 8040759.

5. Afshari P, Yazdizadeh S, Abedi P, et al. The Relation of Diabetes Type 2 with Sexual Function among Reproductive Age Women in Iran, a Case-Control Study. Adv Med. 2017; 2017: 4838923, doi: 10.1155/2017/4838923, indexed in Pubmed: 28484730.

6. Ou HT, Lee TY, Li CY, et al. Incidence of diabetes-related complications in Chinese patients with type 1 diabetes: a population-based longitudinal cohort study in Taiwan. BMJ Open. 2017; 7(6): e015117, doi: 10.1136/bmjopen-2016-015117, indexed in Pubmed: 28637729.

7. Brownlee M. The pathobiology of diabetic complications: a unifying mechanism. Diabetes. 2005; 54(6): 1615-1625, indexed in Pubmed: 15919781.

8. Uruska A, Araszkiewicz A, Zozulinska-Ziolkiewicz D, et al. Insulin resistance is associated with microangiopathy in type 1 diabetic patients treated with intensive insulin therapy from the onset of disease. Exp Clin
Endocrinol Diabetes. 2010; 118(8): 478-484, doi: 10.1055/s-0030-1249635, indexed in Pubmed: 20373280.

9. Rogowicz-Frontczak A, Majchrzak A, Zozulińska-Ziółkiewicz D. Insulin resistance in endocrine disorders - treatment options. Endokrynol Pol. 2017; 68(3): 334-351, doi: 10.5603/EP.2017.0026, indexed in Pubmed: 28660991.

10. Koivisto VA, Stevens LK, Mattock M, et al. Cardiovascular disease and it risk factors in IDDM in Europe. EURODIAB IDDM Complications Study Group. Diabetes Care. 1996; 19(7): 689-697, indexed in Pubmed: 8799621.

11. Schwab KO, Doerfer J, Hecker W, et al. DPV Initiative of the German Working Group for Pediatric Diabetology. Spectrum and prevalence of atherogenic risk factors in 27,358 children, adolescents, and young adults with type 1 diabetes: cross-sectional data from the German diabetes documentation and quality management system (DPV). Diabetes Care. 2006; 29(2): 218-225, indexed in Pubmed: 16443863.

12. Uruska A, Araszkiewicz A, Uruski P, et al. Higher risk of microvascular complications in smokers with type 1 diabetes despite intensive insulin therapy. Microvasc Res. 2014; 92: 79-84, doi: 10.1016/j.mvr.2014.01.002, indexed in Pubmed: 24423616.

13. Uruska A, Michalska A, Ostrowska J, et al. Is cathelicidin a novel marke of diabetic microangiopathy in patients with type 1 diabetes? Clin Biochem. 2017; 50(18): 1110-1114, doi: 10.1016/j.clinbiochem.2017.09.023, indexed in Pubmed: 28964758

14. Nathan DM, Genuth S, Lachin J, et al. Diabetes Control and Complications Trial Research Group. The effect of intensive treatment of diabetes on the development and progression of long-term complications in insulin-dependent diabetes mellitus. N Engl J Med. 1993; 329(14): 977-986, doi: 10.1056/NEJM199309303291401, indexed in Pubmed: 8366922.

15. Cusick M, Meleth AD, Agrón E, et al. Early Treatment Diabetc Retinopathy Study Research Group. Associations of mortality and diabetes complications in patients with type 1 and type 2 diabetes: early treatment diabetic retinopathy study report no. 27. Diabetes Care. 2005; 28(3): 617-625, indexed in Pubmed: 15735198.

16. Balazard F, Le Fur S, Valtat S, et al. Isis-Diab collaborative group. Association of environmental markers with childhood type 1 diabetes mellitus revealed by a long questionnaire on early life exposures and lifestyle in a case-control study. BMC Public Health. 2016; 16(1): 1021, doi: 10.1186/s12889-016-3690-9, indexed in Pubmed: 27682602.

17. Kilpatrick ES, Rigby AS, Atkin SL. A1C variability and the risk of microvascular complications in type 1 diabetes: data from the Diabetes Control and Complications Trial. Diabetes Care. 2008; 31(11): 2198-2202, doi: 10.2337/dc08-0864, indexed in Pubmed: 18650371.

18. Chawla A, Chawla R, Jaggi S. Microvasular and macrovascular complications in diabetes mellitus: Distinct or continuum? Indian J Endocrino Metab. 2016; 20(4): 546-551, doi: 10.4103/2230-8210.183480, indexed in Pubmed: 27366724.

19. Wegner M, Piorunska-Stolzmann M, Araszkiewicz A, et al. Does oxidized LDL contribute to atherosclerotic plaque formation and microvascular complications in patients with type 1 diabetes? Clin Biochem. 2012 45(18): 1620-1623, doi: 10.1016/j.clinbiochem.2012.08.019, indexed in Pubmed: 22960236

20. Shah MS, Brownlee M. Molecular and Cellular Mechanisms of Cardiovascular Disorders in Diabetes. Circ Res. 2016; 118(11): 1808-1829, doi: 10.1161/CIRCRESAHA.116.306923, indexed in Pubmed: 27230643.

21. Rask-Madsen C, King GL. Vascular complications of diabetes: mechanisms of injury and protective factors. Cell Metab. 2013; 17(1): 20-33, doi 10.1016/j.cmet.2012.11.012, indexed in Pubmed: 23312281.

22. Bartke A. Long-lived Klotho mice: new insights into the roles of IGF-1 and insulin in aging. Trends Endocrinol Metab. 2006; 17(2): 33-35, doi 10.1016/j.tem.2006.01.002, indexed in Pubmed: 16458526.

23. Martin A, David V, Quarles LD. Regulation and function of the FGF23/klotho endocrine pathways. Physiol Rev. 2012; 92(1): 131-155 doi: 10.1152/physrev.00002.2011, indexed in Pubmed: 22298654.

24. Yamashita T, Yoshioka $M$, Itoh N. Identification of a novel fibroblast growth factor, FGF-23, preferentially expressed in the ventrolateral thalamic nucleus of the brain. Biochem Biophys Res Commun. 2000; 277(2): 494-498, doi: 10.1006/bbrc.2000.3696, indexed in Pubmed: 11032749.

25. Quarles LD. Role of FGF23 in vitamin D and phosphate metabolism: implications in chronic kidney disease. Exp Cell Res. 2012; 318(9): 1040-1048, doi: 10.1016/j.yexcr.2012.02.027, indexed in Pubmed: 22421513.

26. Fukumoto S, Shimizu Y. Fibroblast growth factor 23 as a phosphotropic hormone and beyond. J Bone Miner Metab. 2011; 29(5): 507-514, doi 10.1007/s00774-011-0298-0, indexed in Pubmed: 21822586.

27. Liu S, Tang W, Zhou J, et al. Fibroblast growth factor 23 is a counter-regulatory phosphaturic hormone for vitamin D. J Am Soc Nephrol. 2006; 17(5): 1305-1315, doi: 10.1681/ASN.2005111185, indexed in Pubmed: 16597685.

28. Haussler MR, Whitfield GK, Kaneko I, et al. The role of vitamin D in the FGF23, klotho, and phosphate bone-kidney endocrine axis. Rev Endoc Metab Disord. 2012; 13(1): 57-69, doi: 10.1007/s11154-011-9199-8, indexed in Pubmed: 21932165. 
29. Oliveira RB, Cancela ALE, Graciolli FG, et al. Early control of PTH and FGF23 in normophosphatemic CKD patients: a new target in CKD-MBD therapy? Clin J Am Soc Nephrol. 2010; 5(2): 286-291, doi: 10.2215/CJN.05420709, indexed in Pubmed: 19965540.

30. Hu X, Ma X, Luo Y, et al. Associations of serum fibroblast growth factor 23 levels with obesity and visceral fat accumulation. Clin Nutr. 2018; 37(1): 223-228, doi: 10.1016/j.clnu.2016.12.010, indexed in Pubmed: 28027796.

31. Tsuji K, Maeda T, Kawane T, et al. Leptin stimulates fibroblast growth factor 23 expression in bone and suppresses renal 1alpha,25-dihydroxyvitamin D3 synthesis in leptin-deficient mice. J Bone Miner Res. 2010; 25(8): 1711-1723, doi: 10.1002/jbmr.65, indexed in Pubmed: 20200981.

32. Yamada S, Giachelli CM. Vascular calcification in CKD-MBD: Roles for phosphate, FGF23, and Klotho. Bone. 2017; 100: 87-93, doi: 10.1016/j. bone.2016.11.012, indexed in Pubmed: 27847254.

33. Donate-Correa J, Martín-Núnez E, Delgado NP, et al. Implications of Fibroblast growth factor/Klotho system in glucose metabolism and diabetes. Cytokine Growth Factor Rev. 2016; 28: 71-77, doi: 10.1016/j. cytogfr.2015.12.003, indexed in Pubmed: 26706229.

34. Kurosu H, Ogawa Y, Miyoshi M, et al. Regulation of fibroblast growth factor-23 signaling by klotho. J Biol Chem. 2006; 281(10): 6120-6123, doi: 10.1074/jbc.C500457200, indexed in Pubmed: 16436388.

35. Słomiński B, Ryba-Stanisławowska M, Skrzypkowska M, et al. The KL-VS polymorphism of KLOTHO gene is protective against retinopathy incidence in patients with type 1 diabetes. Biochim Biophys Acta Mol Basis Dis. 2018; 1864(3): 758-763, doi: 10.1016/j.bbadis.2017.12.015, indexed in Pubmed: 29247834.

36. Kuro-o M, Matsumura Y, Aizawa H, et al. Mutation of the mouse klotho gene leads to a syndrome resembling ageing. Nature. 1997; 390(6655): 45-51, doi: 10.1038/36285, indexed in Pubmed: 9363890.

37. Tohyama O, Imura A, Iwano A, et al. Klotho is a novel beta-glucuronidase capable of hydrolyzing steroid beta-glucuronides. J Biol Chem. 2004; 279(11): 9777-9784, doi: 10.1074/jbc.M312392200, indexed in Pubmed: 14701853.

38. Unger RH. Klotho-induced insulin resistance: a blessing in disguise? Nat Med. 2006; 12(1): 56-57, doi: 10.1038/nm0106-56, indexed in Pubmed: 16397569.

39. Kuro-o M. Klotho and aging. Biochim Biophys Acta. 2009; 1790(10): 1049-1058, doi: 10.1016/j.bbagen.2009.02.005, indexed in Pubmed: 19230844.

40. Kurosu H, Yamamoto M, Clark JD, et al. Suppression of aging in mice by the hormone Klotho. Science. 2005; 309(5742): 1829-1833, doi: 10.1126/science.1112766, indexed in Pubmed: 16123266.

41. Yamamoto M, Clark JD, Pastor JV, et al. Regulation of oxidative stress by the anti-aging hormone klotho. J Biol Chem. 2005; 280(45): 38029-38034, doi: 10.1074/jbc.M509039200, indexed in Pubmed: 16186101.

42. Tzivion G, Dobson M, Ramakrishnan G. FoxO transcription factors; Regulation by AKT and 14-3-3 proteins. Biochim Biophys Acta. 2011; 1813(11): 1938-1945, doi: 10.1016/j.bbamcr.2011.06.002, indexed in Pubmed: 21708191.

43. Razzaque MS. The role of Klotho in energy metabolism. Nat Rev Endocrinol. 2012; 8(10): 579-587, doi: 10.1038/nrendo.2012.75, indexed in Pubmed: 22641000.
44. Ichikawa S, Imel EA, Kreiter ML, et al. A homozygous missense mutation in human KLOTHO causes severe tumoral calcinosis. J Clin Invest. 2007; 117(9): 2684-2691, doi: 10.1172/JCI31330, indexed in Pubmed: 17710231

45. Donate-Correa J, Martín-Núñez E, Martínez-Sanz R, et al. Influence of Klotho gene polymorphisms on vascular gene expression and its relationship to cardiovascular disease. J Cell Mol Med. 2016; 20(1): 128-133, doi: 10.1111/jcmm.12710, indexed in Pubmed: 26538295.

46. Śnit M, Nabrdalik K, Długaszek M, et al. Association of rs 3807337 polymorphism of CALD1 gene with diabetic nephropathy occurrence in type 1 diabetes - preliminary results of a family-based study. Endokrynol Pol. 2017; 68(1): 13-17, doi: 10.5603/EP.2017.0003, indexed in Pubmed: 28255976.

47. Wolf M. Fibroblast growth factor 23 and the future of phosphorus management. Curr Opin Nephrol Hypertens. 2009; 18(6): 463-468, doi: 10.1097/MNH.0b013e328331a8c8, indexed in Pubmed: 19770756.

48. Drüeke TB. Klotho, FGF23, and FGF receptors in chronic kidney disease: a yin-yang situation? Kidney Int. 2010; 78(11): 1057-1060, doi: 10.1038/ki.2010.339, indexed in Pubmed: 21076444.

49. Haruna Y, Kashihara N, Satoh M, et al. Amelioration of progressive renal injury by genetic manipulation of Klotho gene. Proc Natl Acad Sci U S A. 2007; 104(7): 2331-2336, doi: 10.1073/pnas.0611079104, indexed in Pubmed: 17287345.

50. Kim SS, Song SH, Kim InJ, et al. Decreased plasma $\alpha$-Klotho predict progression of nephropathy with type 2 diabetic patients. J Diabetes Complications. 2016; 30(5): 887-892, doi: 10.1016/j.jdiacomp.2016.03.006, indexed in Pubmed: 27037042.

51. Nie F, Wu D, Du H, et al. Serum klotho protein levels and their correlations with the progression of type 2 diabetes mellitus. J Diabetes Complications. 2017; 31(3): 594-598, doi: 10.1016/j.jdiacomp.2016.11.008, indexed in Pubmed: 27916483.

52. Keles N, Dogan B, Kalcik M, et al. Is serum Klotho protective against atherosclerosis in patients with type 1 diabetes mellitus? J Diabetes Complications. 2016; 30(1): 126-132, doi: 10.1016/j.jdiacomp.2015.09.013, indexed in Pubmed: 26601789.

53. Guo $Y$, Zhuang $X$, Huang $Z$, et al. Klotho protects the heart from hyperglycemia-induced injury by inactivating ROS and NF- B-mediated inflammation both in vitro and in vivo. Biochim Biophys Acta Mol Basis Dis. 2018; 1864(1): 238-251, doi: 10.1016/j.bbadis.2017.09.029, indexed in Pubmed: 28982613.

54. Izaguirre M, Gil MJ, Monreal I, et al. The Role and Potential Therapeutic Implications of the Fibroblast Growth Factors in Energy Balance and Type 2 Diabetes. Curr Diab Rep. 2017; 17(6): 43, doi: 10.1007/s11892-017-0866-3, indexed in Pubmed: 28451950.

55. Ors D, Eroglu Altinova A, Yalçın MM, et al. Fibroblast growth factor 21 and its relationship with insulin sensitivity in first-degree relatives of patients with type 2 diabetes mellitus. Endokrynol Pol. 2016; 67(3): 260-264, doi: 10.5603/EP.a2016.0016, indexed in Pubmed: 26884286.

56. Silva AP, Mendes F, Pereira L, et al. Klotho levels: association with insulin resistance and albumin-to-creatinine ratio in type 2 diabetic patients. Int Urol Nephrol. 2017; 49(10): 1809-1814, doi: 10.1007/s11255-017-1646-3, indexed in Pubmed: 28677090.

57. Lin Yi, Sun Z. Antiaging Gene Klotho Attenuates Pancreatic $\beta$-Cell Apoptosis in Type 1 Diabetes. Diabetes. 2015; 64(12): 4298-4311, doi: 10.2337/db15-0066, indexed in Pubmed: 26340932. 


\title{
Funkcja białka Klotho u pacjentów z cukrzycą typu 1
}

\author{
Justyna Flotyńska, Aleksandra Uruska, Aleksandra Araszkiewicz, Dorota Zozulińska-Ziółkiewicz \\ Katedra i Klinika Chorób Wewnętrznych i Diabetologii, Uniwersytet Medyczny w Poznaniu, Polska
}

Artykuł jest tłumaczeniem pracy: Flotyńska J., Uruska A., Araszkiewicz A., Zozulińska-Ziółkiewicz D. Klotho protein function among patients with type 1 diabetes. Endokrynol Pol 2018; 69 (6): 696-700

Należy cytować wersję pierwotną.

Piśmiennictwo dostępne w wersji pierwotnej na stronach 699-700.

\begin{abstract}
Streszczenie
Czynnik wzrostu fibroblastów 23 (FGF23) oraz białko Klotho odgrywają bardzo ważną rolę w regulacji metabolizmu ludzkiego ciała. Z jednej strony białka te promują długowieczność, natomiast z drugiej sprzyjają insulinooporności. Przyspieszone starzenie u pacjentów z cukrzycą typu 1 wskazuje się jako jeden z głównych czynników wpływających na rozwój przewlekłych powikłań choroby. Szlaki sygnałowe indukowane przez insulinę, insulinopodobny czynnik wzrostu (IGF-1) i ich homologi odgrywają ważną rolę w kontrolowaniu procesu starzenia. Ponieważ system FGF23/Klotho wpływa na metabolizm glukozy i ekspresję genów enzymów antyoksydacyjnych, zmiany w jego stężeniu mogą być markerem przewlekłych powikłań cukrzycy lub dodatkową opcją leczenia. Pomimo ogromnego postępu w leczeniu i kontrolowaniu cukrzycy przewlekłe powikłania pozostają ważnym problemem klinicznym. Interesującym zagadnieniem jest związek między stężeniem FGF23/Klotho a czasem trwania choroby, jej przebiegiem, opornością tkanek na działanie insuliny i rozwojem przewlekłych powikłań wśród pacjentów z cukrzycą typu 1. (Endokrynol Pol 2018; 69 (6): 701-704)
\end{abstract}

Słowa kluczowe: cukrzyca typu 1; białka długowieczności; przewlekłe powikłania cukrzycy

\section{Wstęp}

Cukrzyca typu 1 (CT1) jest przewlekłą chorobą autoimmunologiczną [1]. Liczba osób z CT1 wciąż rośnie na całym świecie [2]. Pacjenci z CT1 wykazują gorszą jakość życia w porównaniu ze zdrową populacją [3]. Zbyt późno postawiona diagnoza i brak kontroli choroby prowadzą do rozwoju przewlekłych powikłań, które powodują niepełnosprawność, niezdolność do pracy oraz zwiększają przedwczesną śmiertelność [4-6]. Wśród tradycyjnych czynników ryzyka rozwoju przewlekłych powikłań kluczową rolę odgrywają hiperglikemia [7] oraz insulinooporność (IR, insulin resistance) [8], obejmująca zmniejszoną wrażliwość mięśni, tkanki tłuszczowej oraz wątroby na działanie insuliny [9]. Dodatkowymi czynnikami ryzyka są dyslipidemia [10], nadciśnienie tętnicze (NT) [11], palenie papierosów [12] oraz przewlekły stan zapalny [7]. Badanie The Diabetes Control and Complications Trial (DCCT) [1] wykazało, że u pacjentów z CT1 właściwa kontrola metaboliczna, zapewniona przez intensywną insulinoterapię, ma podstawowe znaczenie w zapobieganiu i leczeniu angiopatii. Długotrwała normalizacja wartości glukozy we krwi może znacznie zmniejszyć ryzyko wystąpienia i opóźnić progresję przewlekłych powikłań cukrzycy [13, 14]. Jednak pomimo postępu, jaki dokonał się $\mathrm{w}$ zakresie rozpoznawania i leczenia CT1, przewlekłe powikłania nadal pozostają istotnym problemem klinicznym. Retinopatia jest wiodącą przyczyną ślepoty, cukrzycowa choroba nerek jest główną przyczyną schyłkowej niewydolności nerek, a neuropatia cukrzycowa jest na pierwszym miejscu wśród przyczyn nieurazowych amputacji kończyn dolnych [15]. Dlatego wciąż poszukiwane są nowe, nietradycyjne czynniki ryzyka cukrzycowej angiopatii u chorych na CT1 [16].

Patogeneza przewlekłych powikłań, które występują u pacjentów z CT1, jest bardzo skomplikowana. Najważniejszym czynnikiem jest dysfunkcja śródbłonka powodująca mikroangiopatię, makroangiopatię i neuropatię [17]. Pacjenci chorujący na CT1 z obecnymi powikłaniami mikronaczyniowymi prezentują większe ryzyko przyspieszonej miażdżycy, która ostatecznie kończy się incydentami naczyniowo-mózgowymi i sercowo-naczyniowymi oraz przedwczesną śmiercią [18]. Główną przyczyną uszkodzeń mikronaczyniowych jest dysfunkcja śródbłonka spowodowana wewnątrznaczyniowym stresem oksydacyjnym $[13,19]$. Hiperglikemia 
z IR są w głównej mierze odpowiedzialne za rozwój chorób sercowo-naczyniowych wśród pacjentów z CT1 [20]. Powodują one powstawanie reaktywnych form tlenu (RFT), które — oddziałując przez dłuższy czas na poziomie subkomórkowym - prowadzą do upośledzenia funkcji komórek oraz uszkodzeń sercowo-naczyniowych [20]. Reaktywne formy tlenu aktywują polimerazę nukleotydową ADP rybozy (PARP), kierując wczesne półprodukty glikolityczne na patogenne szlaki sygnałowe. Zmiany te powodują obniżoną biogenezę mitochondrialną oraz zaburzoną synchronizację metabolizmu glukozy i lipidów [20]. Innym ważnym patomechanizmem powodującym mikroangiopatię jest stan zapalny [7]. Nadprodukcja RFT w wyniku zmienionego metabolizmu glukozy i tworzenia się produktów końcowych zaawansowanej glikacji (AGE, advanced glycation end-products) aktywuje czynnik jądrowy $\kappa \mathrm{B}(\mathrm{NF \kappa B})$ i inne szlaki prozapalne. W połączeniu z IR komórek zaburzenia te powodują dysfunkcję śródbłonka, objawiającą się zwiększoną ekspresją cząsteczek adhezyjnych i innymi niekorzystnymi zmianami [21]. Obecnie uważa się, że wspomniane mechanizmy prowadzące do rozwoju przewlekłych powikłań są główną przyczyną przespieszonego starzenia wśród pacjentów z cukrzycą. Szlaki sygnałowe indukowane przez insulinę, insulinopodobny czynnik wzrostu (IGF-1) i ich homologi odgrywają ważną rolę w kontrolowaniu starzenia się wielu organizmów [22]. Ponieważ kompleks FGF23/Klotho wpływa na procesy związane z metabolizmem glukozy i regulację ekspresji genów enzymów antyoksydacyjnych, zmiany w jego stężeniu mogą być ważnym źródłem informacji na temat rozwoju przewlekłych powikłań cukrzycy.

\section{Funkcja FGF23}

Czynnik wzrostu fibroblastów 23 (FGF23) i białko Klotho są ważną częścią układu regulującego metabolizm witaminy D i stężenia fosforanów. Czynnik FGF23 to jeden z najnowszych członków rodziny FGF, hormon fosfatouryczny, syntetyzowany i wydzielany przez osteoblasty i osteocyty, a w mniejszym stopniu przez ślinianki, mięśnie szkieletowe, gruczoły piersiowe, wątrobę i mięsień sercowy. Głównym narządem docelowym działania tego białka są nerki [23-25]. Hamuje on nerkową reabsorpcję fosforanów i powoduje ich wydalanie poprzez hamowanie kotransportera sodowo-fosforanowego oraz powoduje zmniejszenie stężenia 1,25 (OH) witaminy D3, hamując $1 \alpha$-hydroksylazę i stymulując 24-hydroksylazę. Dodatkowo, FGF23 hamuje wydzielanie parathormonu (PTH) (26). Nadmiar FGF23 prowadzi do hipofosfatemii, zmniejszenia stężenia $1,25(\mathrm{OH})_{2} \mathrm{D}$, a zatem do krzywicy lub osteomalacji. Z drugiej strony, niedobór FGF23 powoduje

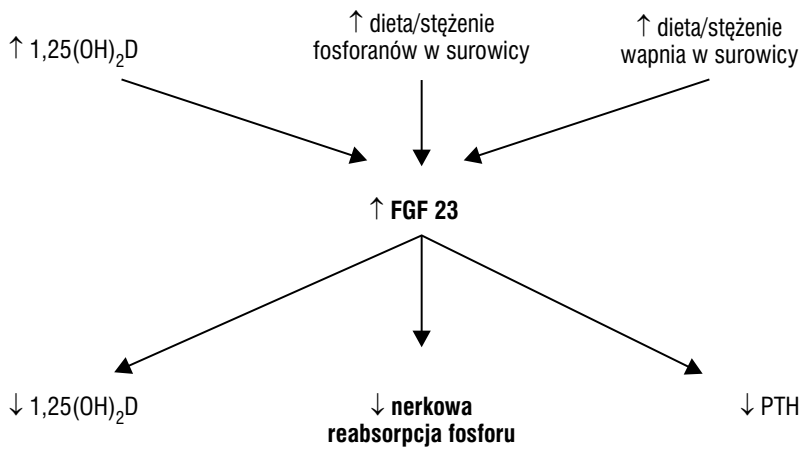

Rycina 1. Regulacja stężenia czynnika wzrostu fibroblastów 23 (FGF23)

sytuację odwrotną, co implikuje tworzenie zwapnień w tkankach miękkich. Hiperfosfatemia i 1,25 $(\mathrm{OH})_{2} \mathrm{D}$ stymulują wydzielanie FGF23, natomiast spadek dostarczania fosforanów działa hamująco [25].

Literatura wskazuje, że ogólnoustrojowy poziom fosforanów i stężenie witaminy D mają najbardziej znaczący wpływ na stężenie FGF23 [27-29] (ryc. 1). Mniej znanym, choć wydaje się, że istotnym czynnikiem regulacyjnym, jest leptyna. Ostatnie badania donoszą o związku między otyłością brzuszną a zwiększeniem stężenia FGF23 [30]. Stymuluje ona syntezę FGF23 w kościach. Istnieje związek podwyższonego stężenia leptyny i FGF23 z dyslipidemią i masą tkanki tłuszczowej [31]. Może to stanowić czynnik ryzyka rozwoju IR, zespołu metabolicznego (ZM) i zgonów z przyczyn sercowo-naczyniowych, szczególnie u pacjentów z długotrwałą CT1 i dekompensacją metaboliczną [32]. Coraz więcej danych pokazuje, że rodzina czynników wzrostu fibroblastów wpływa na regulację i homeostazę węglowodanów [33].

\section{Klotho jako kofaktor FGF23}

Białko Klotho jest kofaktorem FGF23 i niezbędnym białkiem do funkcjonowania całego kompleksu [34]. Jest hormonem krążącym we krwi, zaangażowanym w sygnalizację na szlaku insuliny, stan zapalny i homeostazę naczyniową poprzez ochronne działanie na śródbłonek i funkcje przeciwutleniające [35]. Ekspresja Klotho zachodzi w różnych tkankach. Głównym miejscem syntezy są cewki dystalne w nerce, sploty naczyniówkowe komór mózgu i przytarczyce. Występuje również w wątrobie, trzustce i białej tkance tłuszczowej [36]. Ma formę związaną z błoną oraz formę wydzielniczą. Białko Klotho wykazuje aktywność $\beta$-glukuronidazy, a jego forma wydzielnicza jest endokrynnym regulatorem funkcji glikoprotein na powierzchni komórek [37]. System FGF23/Klotho działa odwrotnie $\mathrm{w}$ stosunku do witaminy $\mathrm{D}$, a w świetle ostatnich badań odgrywa porównywalną rolę do osi PTH-witamina D [23]. 


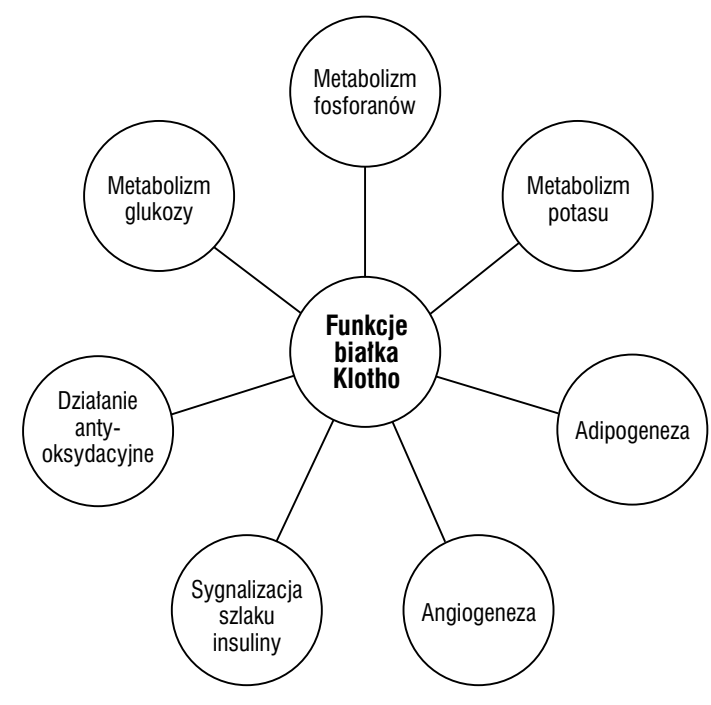

Rycina 2. Funkcje biatka Klotho

\section{Funkcja białka Klotho w organizmie człowieka}

Klotho jest bardzo ważnym białkiem o szerokim spektrum działania (ryc. 2). Wpływa także na procesy związane z metabolizmem glukozy [38]. Białko zaangażowane jest $\mathrm{w}$ tłumienie szlaku insuliny/IGF-1, co przekłada się na udział w regulacji funkcji oraz wzrostu komórek. Szlaki sygnalizacyjne inicjowane przez insulinę, insulinopodobny czynnik wzrostu (IGF-1, insulin-like growth factor 1) oraz ich homologi odgrywają istotną rolę w kontroli starzenia się wielu organizmów [22]. Białko to zaburza fosforylację, w której pośredniczy insulina, w konsekwencji hamując aktywację dalszych białek szlaku enzymatycznego. $W$ badaniach in vitro udowodniono, iż białko to może również hamować fosforylację receptorów uprzednio aktywowanych przez insulinę bądź IGF-1. Aktywność sekrecyjnego białka Klotho jest specyficzna dla receptorów insuliny i IGF-1, ponieważ nie wykazuje podobnego efektu w stosunku do receptorów płytkowego czynnika wzrostu (PDGF, plateled-derived growth factor) i czynnika wzrostu naskórka (EGF, epidermal growth factor), które mają aktywność kinaz tyrozynowych $[39,40]$. Aktywność enzymatyczna Klotho skłania do sugestii, że może także modyfikować N-glikany receptorów insuliny i IGF-1, przez co blokować ich aktywność i/lub zmniejszać liczbę tych receptorów na powierzchni komórek. Blokuje stymulowany insuliną wychwyt glukozy i przyczynia się do rozwoju IR oraz wszystkich tego konsekwencji [39]. Sugeruje się, że do przedłużenia żywotności przyczynia się współdziałanie dwóch mechanizmów: hamowanie sygnalizacji IGF-1 oraz zwiększenie oporności na szlak oksydacyjny [41]. Zablokowanie transmisji sygnału na szlaku zależnym od insuliny/IGF-1 prowadzi do zahamowania kinazy
Akt. Aktywna kinaza Akt fosforyluje czynnik transkrypcyjny FOXO. Tylko nieufosforylowany czynnik FOXO zlokalizowany w jądrze komórkowym spełnia funkcję czynnika transkrypcyjnego. Białka należące do rodziny FOXO wpływają na różnicowanie komórek, embriogenezę, nowotworzenie oraz regulację metabolizmu [42]. Istotną funkcją jest regulacja ekspresji genów enzymów antyoksydacyjnych, takich jak katalaza czy mitochondrialna manganowa dysmutaza ponadtlenkowa (SOD2). Enzymy te, usuwając reaktywne formy tlenu, przyczyniają się do redukcji stresu oksydacyjnego, co może być czynnikiem kluczowym w procesie hamowania starzenia się organizmów, u których doszło do inhibicji szlaku insuliny/IGF-1 [39]. Białko Klotho zwiększa rozrost tkanki tłuszczowej, a myszy pozbawione tego genu są oporne na rozwój otyłości indukowanej dietą o dużej zawartości tłuszczu [43]. Na modelach zwierzęcych wykazano, że mutacje inaktywujące gen Klotho powodują skrócenie czasu przeżycia i wiele zaburzeń, których istotą jest przedwczesne starzenie. Do zaburzeń tych należą osteoporoza, hipogonadyzm hipogonadotropowy, miażdżyca, zanik skóry i zmiany neurodegeneracyjne. Dodatkowo stwierdzono, że u myszy pozbawionych genu FGF23 i Klotho - oprócz hiperfosfatemii i zwiększonego stężenia $1,25(\mathrm{OH}) 2 \mathrm{D}$ - dochodzi do zaniku grasicy, obniżenia stężenia triglicerydów i glukozy oraz wzrostu stężenia cholesterolu [36]. O istotnej funkcji Klotho świadczą badania naukowe na temat ciężkich zwapnień guzowatych w wyniku mutacji missensownej ludzkiego genu kodującego białko Klotho [44]. Ponadto, najnowsze doniesienia wykazują związek naczyniowej ekspresji tego białka z cukrzycą oraz chorobą wieńcową [45]. Z literatury wynika zatem, że system FGF23/Klotho — oprócz regulacji gospodarki elektrolitowej — pełni bardzo ważną funkcję $\mathrm{w}$ regulacji metabolizmu ustroju. Z jednej strony promuje długowieczność, z drugiej natomiast — rozwój IR.

\section{Czy istnieje związek pomiędzy stężeniem białka Klotho w surowicy krwi a cukrzycą typu 1?}

Cukrzycowa choroba nerek jest jednym z najpoważniejszych powikłań u pacjentów z CT1 oraz jednym z głównych czynników predykcyjnych przedwczesnej śmierci [46]. Zaburzenia czynności nerek powodują zmiany stężenia opisanych białek. Przewlekła choroba nerek niesie za sobą zwiększone stężenie FGF23 z jednoczasowym zmniejszeniem stężenia białka Klotho. Już w 2-3 fazie przewlekłej choroby nerek, to jest w stadium, w którym fosfatemia jest jeszcze prawidłowa, a stężenie PTH prawidłowe lub umiarkowanie podwyższone, następuje wzrost stężenia FGF23 $[47,48]$. Myszy bez genu Klotho i pacjenci ze schył- 
kową niewydolnością nerek mają wspólne cechy, takie jak hiperfosfatemia, zwapnienia naczyń czy wysokie stężenie FGF23 [49]. Cukrzyca jako choroba przewlekła wywołuje szereg powikłań, w tym nefropatię. Sugeruje się także, że stężenie białka Klotho w osoczu, a dokładniej zanik kompensacyjnego wzrostu stężenia w surowicy, może być wczesnym markerem do przewidywania pogorszenia czynności nerek u pacjentów z cukrzycą typu $2[50,51]$. Wiemy również, że białko Klotho może mieć działanie ochronne na rozwój miażdżycy i dysfunkcję śródbłonka u pacjentów z typem 1 cukrzycy [52]. Zespół badawczy pod przewodnictwem Guo ujawnil, że Klotho może wywierać działanie kardioprotekcyjne poprzez ochronę komórek przed stanem zapalnym i stresem oksydacyjnym. Praca ta po raz pierwszy wykazała, że przeciwstarzeniowe białko Klotho może być potencjalnym środkiem terapeutycznym w leczeniu kardiomiopatii cukrzycowej, hamując stres oksydacyjny oraz stan zapalny [53]. Ostatnio czynniki wzrostu fibroblastów stały się atrakcyjnymi punktami w leczeniu chorób metabolicznych, a wyniki badań naukowych wskazują na wykorzystanie FGF jako potencjalnych biomarkerów wczesnej diagnostyki chorób metabolicznych [54]. Jednak wciąż niewiele jest badań wykazujących podobne korelacje u pacjentów z cukrzycą typu 1. Ciekawym pytaniem jest, czy wśród osób z cukrzycą typu 1, wraz ze wzrostem stężenia FGF23, a co za tym idzie spadkiem koncentracji białka Klotho, ujawniają się i nasilają cechy starzenia.

\section{Podsumowanie}

Obecnie brakuje nam danych wskazujących na zmiany stężenia FGF23 i białka Klotho u osób z CT1. Literatura donosi, że stężenia białek z rodziny czynników wzrostu fibroblastów są zwiększone u krewnych pierwszego stopnia chorych na CT2 ze stanem przedcukrzycowym i że istnieje silny związek między stężeniem czynnika wzrostu fibroblastów 21 (FGF21) a otyłością i wrażliwością na insulinę [55]. Wiemy także, że na poziom Klotho u pacjentów z CT1 może wpływać niewydolność nerek, hiperglikemia i wysokie dawki insuliny [56]. Możliwe jest także, że syntetyzowane w trzustce białko Klotho pełni funkcję zupełnie inną od poznanej. Ostatnie badania donoszą, iż synteza w komórkach trzustki powoduje tłumienie apoptozy komórek beta u pacjentów chorujących na CT1 [57], a wyniki najnowszych badań sugerują, że funkcjonalny wariant genu Klotho chroni przed rozwojem retinopatii u pacjentów z CT1 [35]. Ciekawym zagadnieniem pozostaje związek stężenia tych białek z częstością oraz rodzajem powikłań u osób chorujących na CT1, a także z długością trwania choroby i rozwojem IR, szczególnie w kwestii białka Klotho identyfikowanego jako białko starzenia i długowieczności. Potrzebujemy więcej badań, aby wyraźnie określić związek pomiędzy stężeniem FGF23 i białka Klotho z CT1.

\section{Podziękowanie}

Praca została sfinansowana z grantu Polskiego Towarzystwa Diabetologicznego. 